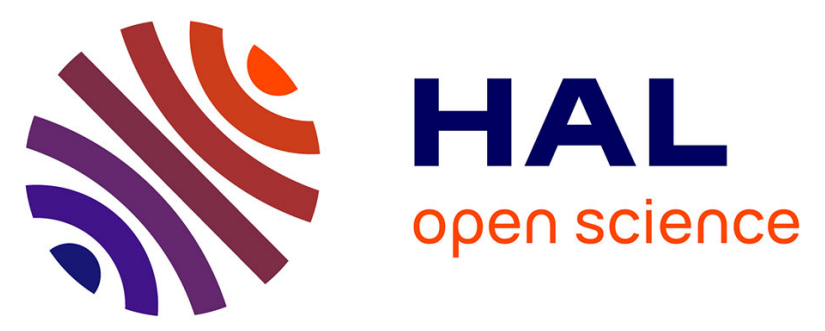

\title{
Assessing Fit of Capacity Planning Methods for Delivery Date Setting: An ETO Case Study
}

Swapnil Bhalla, Erlend Alfnes, Hans-Henrik Hvolby

\section{To cite this version:}

Swapnil Bhalla, Erlend Alfnes, Hans-Henrik Hvolby. Assessing Fit of Capacity Planning Methods for Delivery Date Setting: An ETO Case Study. IFIP International Conference on Advances in Production Management Systems (APMS), Sep 2019, Austin, TX, United States. pp.265-273, 10.1007/978-3-03029996-5_31.hal-02460517

\section{HAL Id: hal-02460517 https://hal.inria.fr/hal-02460517}

Submitted on 30 Jan 2020

HAL is a multi-disciplinary open access archive for the deposit and dissemination of scientific research documents, whether they are published or not. The documents may come from teaching and research institutions in France or abroad, or from public or private research centers.
L'archive ouverte pluridisciplinaire HAL, est destinée au dépôt et à la diffusion de documents scientifiques de niveau recherche, publiés ou non, émanant des établissements d'enseignement et de recherche français ou étrangers, des laboratoires publics ou privés. 


\title{
Assessing Fit of Capacity Planning Methods for Delivery Date Setting: An ETO Case Study
}

\author{
Swapnil Bhalla ${ }^{1 凶[0000-0003-4905-2488]}$, Erlend Alfnes ${ }^{10000-0002-9892-3916]}$, and \\ Hans-Henrik Hvolby ${ }^{1,2}[0000-0002-5574-5216]$ \\ 1 Department of Mechanical and Industrial Engineering, NTNU, Norwegian \\ University of Science and Technology, Trondheim, Norway \\ 2 Department of Materials and Production, Centre for Logistics, Aalborg University, \\ Aalborg, Denmark \\ swapnil.bhalla@ntnu.no
}

\begin{abstract}
The paper studies an engineer-to-order (ETO) manufacturing firm. A novel approach is used to assess the fit of capacity planning methods in the planning environment of the firm, and towards delivery date setting, which is of strategic importance for ETO firms.
\end{abstract}

Keywords: Engineer-to-order (ETO) - strategic fit · delivery date or due date capacity planning rough-cut capacity planning (RCCP)

\section{Introduction}

Developing product designs for specific customer orders allows manufacturers to deliver customised products that address customers' unique requirements. This manufacturing approach, known as customer-driven manufacturing, is a key concept for future factories $[9,19,26]$. Such a customer-driven approach to manufacturing is prevalent among enterprises producing high-value capital products, such as shipbuilding, offshore equipment manufacturing, etc. [11,22]. Based on the customer order decoupling point (CODP) framework, such manufacturing contexts are characterised by a supply chain strategy or product delivery strategy known as engineer-to-order (ETO) [17]. While firms producing high-value products benefit from an ETO strategy, which enables them to address specific customer requirements, they also operate in relatively complex planning environments due to increased uncertainty regarding specifications of the product and production process [23].

Customising products for every customer's requirements leads to newness within order fulfilment activities for each customer order, which include engineering, purchasing, production, etc. The newness of order fulfilment activities for a product is managed by organising these activities as a project [27]. A precursor to planning a project and confirmation of customer orders is the customer enquiry stage, where estimated price, project delivery date, etc. should be quoted by the manufacturer [23]. The acceptance of these delivery dates by potential customers are often a criterion for confirmation of customer orders [23]. Due to 
the uncertainty in product and process specifications, and the newness or nonrepetitiveness of production activities, identifying reliable production delivery dates at this stage is not a trivial task in these manufacturing environments. It is worth clarifying that while 'project delivery date' is used here to refer to the date promised to the customer for handing over the finished product, 'production delivery date' refers to the estimated date when production is expected to be completed, which precedes the project delivery date. The possibility to determine reliable production delivery dates through capacity planning in ETO (and make-to-order (MTO)) environments, is a primary criteria for applicability of production planning and control (PPC) systems in these environments [23].

The fit between PPC systems and corresponding planning environment, has often been emphasised as consequential to manufacturers' performance $[1,16$, 24]. Motivated by the importance of this fit towards improving manufacturing performance, different frameworks for mapping planning environments have been proposed in literature $[3,13,18,20]$. These frameworks for mapping planning environments are intended to be starting points for identifying suitable PPC systems.

This paper presents a case study that set out to investigate the applicability of relevant theoretical knowledge to delivery date setting practice in ETO manufacturing. Through the case study, the paper also demonstrates a novel approach for investigating how the mapping of a planning environment can be used to assess the fit of PPC methods, as called for by Buer et. al. [3] in possibilities for future work.

The paper is organised as follows. Section 2 contextualises this paper using literature. Section 3 outlines relevant capacity planning techniques. Section 4 presents the research framework and case study. Section 5 serves as a brief conclusion to the paper.

\section{Delivery date setting in ETO manufacturing}

The strategic importance of estimating, quoting and setting production delivery dates for customised manufacturing environments such as ETO and MTO, has been emphasised often in literature $[12,14,15,25,29]$. The repeatedly emphasised importance has triggered much research on the subject. However, much of the literature is found to be primarily focused on MTO contexts. Undeniably, firms operating with strategies that are a hybrid of ETO and MTO can be found in practice $[19,21]$. Nevertheless, the primary difference between the two strategies is the engineering aspect, which may introduce uncertainty into the planning environment depending on the level of customisation [29]. As a result, delivery date setting approaches applicable in MTO contexts may not demonstrate equivalently satisfactory performance in ETO contexts. The remainder of this section discusses some salient contributions to delivery date setting literature to contextualise the contribution of this paper.

Zorzini et. al. [28] studied the delivery date setting process at 15 capital goods manufacturers. They report that majority of the studied firms opted to 
perform aggregated capacity analysis for quoting delivery dates, as compared to detailed or no workload analysis. While the sampled firms using aggregated capacity analysis are scattered across the spectrum of customisation and complexity, Zorzini et. al. [28] point out that the assembly process was found to be a fixed bottleneck resource for all of these firms. However, this might not be the case for all ETO environments. It was also not found to be true for our case study context where historically, different machining resources have been observed to be the bottleneck resource for different products. Further, among the firms sampled by Zorzini et. al. [28], it is also not clear how firms across different levels of customisation differently manage uncertainties regarding product and process specification. Their proposed model assumes that average lead times can be estimated based on past orders, but the validity of this assumption can be expected to vary with the level of customisation and size of the product portfolio.

Ebadian et. al. [7] propose a heirarchical PPC model to support delivery date setting, which assumes that incoming orders can be prioritised according to the service level desired for different customers. Carvalho et. al. [6] present an optimisation approach developed for tactical capacity planning under uncertainty in an ETO firm, calling for exploration of the validity of the proposed approach in other ETO contexts. As outlined above through the discussed literature, context-specificity can be observed as a common feature among most research on delivery date setting in ETO. While these are valuable contributions to theory, generalised validity of the findings is only limited. This highlights the contingent nature of the applicability of delivery date setting methods, as also argued by Zorzini et. al. [29] for taking a contingency theory approach to studying customer enquiry management. Therefore, the case study presented in this paper assesses the applicability of basic theoretical methods in an ETO setting, while explicitly demonstrating the approach, which can be replicated in other ETO contexts for assessing applicability of seemingly relevant methods.

\section{Rough-cut Capacity Planning}

Capacity planning refers to "the process of determining the amount of capacity required to produce in the future" [2]. It entails different activities at different hierarchical levels of PPC, such as strategic or long-term resource requirement planning, rough-cut capacity planning (RCCP) on a tactical or master production scheduling (MPS) level, and detailed capacity requirements planning (CRP) at the material requirements planning (MRP) level [2]. As emphasised frequently

in literature, delivery date setting is most commonly observed on a tactical level of PPC [5, 10, 23, 28], and therefore, RCCP methods can be classified as most relevant for delivery date setting. This section briefly presents three basic RCCP methods that are later assessed for their fit to the case environment and for their capability to support delivery date setting. The methods are explained using descriptions from Vollman et. al. [24] and the APICS dictionary [2].

Capacity planning using overall factors (CPOF). Using overall factors for RCCP is a relatively simple approach where the MPS is used as the starting 
point. The scheduled quantities of end products in different time buckets serve as basis for estimating the capacity requirements for different work centres, by applying historical percentages to the total number of hours for producing the item. This essentially gives the estimated workload requirement from different work centres for producing the scheduled quantities, without consideration of the actual timing of the capacity requirement projections. The advantages offered by this approach are minimal data requirements and computational simplicity.

Capacity planning using capacity bills (CPCB). Using capacity bills follows a similar computational procedure as $\mathrm{CPOF}$, but differs in the data requirements. Instead of using historical percentages for different work centres, as in CPOF, $\mathrm{CPCB}$ requires bill-of-material (BOM) and routing data with labour-hour or machine-hour data for each operation. Not unlike CPOF, CPCB also does not consider the production lead times, and capacity requirements are not timephased.

Capacity planning using resource profiles (CPRP). Among the three basic RCCP techniques, using resource profiles for capacity planning is the most sophisticated. It takes production lead times into account, and provides timephased projections of capacity requirements. Using the MPS, BOM and routing data, capacity requirements are estimated as in CPCB. These estimates are further utilised to develop time-phased projections by offsetting the capacity requirements.

\section{Case study}

The case company is a supplier of equipment for the maritime industry. The main products and spare parts for previously sold products constitute the manufacturing activities, which are undertaken at the same facility. Their products can be broadly classified into four types, where every type has various sub-types and size alternatives that essentially serve as templates for tailoring the product designs to specific customer requirements. The cumulative production volume of different product types is typically below 500 units per year. Presently, at the customer enquiry stage, production delivery dates are determined using a method that is a hybrid of CPOF and CPRP methods. The product templates and experience from past projects are used to estimate the total workload for a project and consequently, workloads for different work centres. These workloads are then offset in time to get time-phased projections of capacity requirements, and delivery dates are estimated based on these projections. Maintaining delivery precision for the production department has been challenging, and has worsened in recent years with widening of the product portfolio and variations in the product mix of demand.

\subsection{Methodology}

The purpose of the case study was to better understand the challenges in setting delivery dates in ETO environments. As it was revealed during earlier collaboration that the case company recognise delivery date setting as one of the 


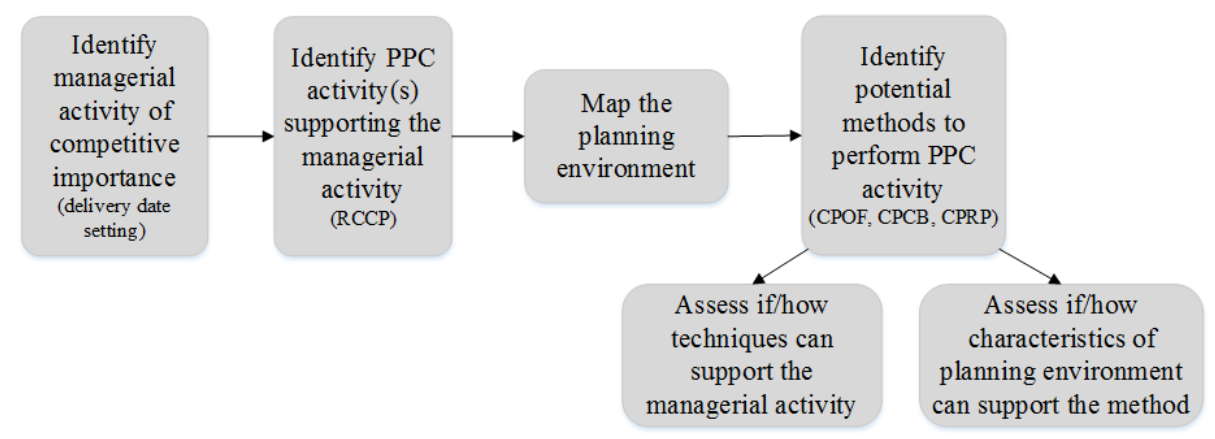

Fig. 1. Research framework underlying the case study

challenging managerial tasks, the firm served as an appropriate context for this case study. The case sample presented in this paper is limited to a single indepth case study due to space constraints and can be expanded in the future to test generalisability of the findings. Figure 1 shows the underlying research framework for the case study process, which can be utilised in future studies to assess fit of planning activities or PPC systems towards planning environments.

\subsection{Assessing fit}

The case company is mapped using Buer et. al.'s [3] framework, where characteristics of a planning environment are classified into product, market and manufacturing process related variables. The fit of the RCCP methods is then assessed towards the clustered environmental variables and delivery date setting, based on a combination of literature synthesis and logical assumptions, as shown in Table 1. The planning environment is characterised as follows.

Product-related variables. CODP placement: ETO-MTO; level of customisation: some specifications are allowed; product variety: high; BOM complexity: 3-5 levels; product data accuracy: low-medium; level of process planning: fully designed process.

Market-related variables. P/D ratio $<1$; demand type: customer order allocation; source of demand: customer order; volume/frequency: few large customer orders per year; frequency of customer demand: unique-sporadic; time distributed demand: annual figure; demand characteristics: dependent; type of procurement ordering: order by order procurement; inventory accuracy: medium. The market-related variables can be further distinguished into demand-related (from $\mathrm{P} / \mathrm{D}$ ratio to demand characteristics) and supply-related variables (type of procurement and inventory accuracy).

Manufacturing process characteristics. Manufacturing mix: mixed products; shop floor layout: fixed-position - cell; type of production: single-unit - smallseries; throughput time: months - weeks; number of major operations: high; batch size: equal to customer quantity; frequency of production order repetition: infrequent repetition; fluctuations of capacity requirements: medium; planning 
Table 1. Assessing fit of RCCP methods towards planning environment and delivery date setting.

\begin{tabular}{|c|c|c|c|}
\hline & Overall factors & Capacity bills & Resource profiles \\
\hline & $\begin{array}{l}\text { CPOF reflects a poor fit } \\
\text { to the product charac- } \\
\text { teristics. Values of mu- } \\
\text { tually causative variables } \\
\text { such as CODP, customisa- } \\
\text { tion, product variety, BOM } \\
\text { complexity and data accu- } \\
\text { racy [3] render CPOF un- } \\
\text { reliable for the case envi- } \\
\text { ronment. This is consistent } \\
\text { with CPOF's success crite- } \\
\text { ria of flat BOM }[13,24] \text {. }\end{array}$ & $\begin{array}{l}\text { CPCB reflects a poor fit to } \\
\text { the product characteristics. } \\
\text { This is primarily due to } \\
\text { relatively low product data } \\
\text { accuracy, which is detri- } \\
\text { mental to the use of CPCB } \\
\text { [8]. Product data entails } \\
\text { detailed BOM and rout- } \\
\text { ing data, the availability } \\
\text { and reliability of which, are } \\
\text { integral to the success of } \\
\text { CPCB [4]. }\end{array}$ & $\begin{array}{l}\text { CPRP reflects a poor fit } \\
\text { to the product characteris- } \\
\text { tics. Performance of CPRP, } \\
\text { like CPCB, relies on the } \\
\text { availability and reliability } \\
\text { of detailed BOM, rout- } \\
\text { ing data and time stan- } \\
\text { dards, accuracy of which } \\
\text { is significantly low during } \\
\text { RCCP. Customisation and } \\
\text { high product variety indi- } \\
\text { rectly contribute to this [3]. }\end{array}$ \\
\hline & $\begin{array}{l}\text { CPOF reflects a poor } \\
\text { fit to the market char- } \\
\text { acteristics, and more } \\
\text { specifically, to the demand- } \\
\text { related variables such as } \\
\text { customer-allocated and } \\
\text { customer order-originated } \\
\text { demand, low frequency } \\
\text { and uniqueness of demand. } \\
\text { While a P/D ratio }<\text {. } \\
\text { is a favourable situation } \\
\text { for the fit of CPOF [13], } \\
\text { the overall fit is rendered } \\
\text { poor by other majority of } \\
\text { variables. }\end{array}$ & $\begin{array}{l}\text { CPCB reflects a poor fit } \\
\text { to the market character- } \\
\text { istics, and specifically, to } \\
\text { demand-related charac- } \\
\text { teristics. However, these } \\
\text { characteristics affect the fit } \\
\text { of CPCB indirectly rather } \\
\text { than directly. Dependent } \\
\text { demand influences time } \\
\text { distribution of demand [3], } \\
\text { which in turn influences } \\
\text { the CODP placement [3], } \\
\text { and leading to the unavail- } \\
\text { ability of BOM and route } \\
\text { during RCCP. }\end{array}$ & $\begin{array}{l}\text { CPRP reflects a poor fit } \\
\text { to the market characteris- } \\
\text { tics of the planning envi- } \\
\text { ronment. Demand-related } \\
\text { characteristics that cause } \\
\text { CPCB to be a poor fit to } \\
\text { the planning environment, } \\
\text { also cause CPRP to have } \\
\text { a poor fit. None of the } \\
\text { discussed RCCP methods } \\
\text { are influenced by supply- } \\
\text { related characteristics, as } \\
\text { on-hand stocks of compo- } \\
\text { nents are not considered in } \\
\text { any of them }[13] \text {. }\end{array}$ \\
\hline & $\begin{array}{l}\text { CPOF reflects a poor fit } \\
\text { to the manufacturing pro- } \\
\text { cess due to environmental } \\
\text { characteristics such as non- } \\
\text { homogeneous manufactur- } \\
\text { ing mix } 13] \text {, production in } \\
\text { single-unit or small series, } \\
\text { long throughput times, rel- } \\
\text { atively high number of } \\
\text { operations and planning } \\
\text { points, and infrequent rep- } \\
\text { etition of production or- } \\
\text { ders. }\end{array}$ & $\begin{array}{l}\text { CPCB reflects a poor to } \\
\text { neutral fit to the process } \\
\text { characteristics of the plan- } \\
\text { ning environment. Lack of } \\
\text { homogeneity in the man- } \\
\text { ufacturing mix does not } \\
\text { cause any particular chal- } \\
\text { lenges in using CPCB, as } \\
\text { it uses detailed bill of re- } \\
\text { sources [13]. Large number } \\
\text { of major operations is ex- } \\
\text { pected to negatively influ- } \\
\text { ence the CPCB's reliability. }\end{array}$ & $\begin{array}{l}\text { CPRP reflects a neutral to } \\
\text { good fit to the manufac- } \\
\text { turing process characteris- } \\
\text { tics of the planning envi- } \\
\text { ronment. A high number } \\
\text { of major manufacturing op- } \\
\text { erations is expected to in- } \\
\text { crease the importance of } \\
\text { offsetting the capacity re- } \\
\text { quirements in time for reli- } \\
\text { able projections, thus qual- } \\
\text { ifying CPRP to have the } \\
\text { best fit. }\end{array}$ \\
\hline & $\begin{array}{l}\text { Using CPOF for RCCP is } \\
\text { expected to provide unre- } \\
\text { liable delivery dates, as it } \\
\text { does not offset capacity re- } \\
\text { quirements in time. }\end{array}$ & $\begin{array}{l}\text { Using CPCB for RCCP is } \\
\text { expected to provide unre- } \\
\text { liable delivery dates, as it } \\
\text { does not offset capacity re- } \\
\text { quirements in time. }\end{array}$ & $\begin{array}{l}\text { Using CPRP is expected to } \\
\text { give reliable delivery dates, } \\
\text { as it offsets capacity re- } \\
\text { quirements in time to get } \\
\text { time-phased projections. }\end{array}$ \\
\hline
\end{tabular}


points: medium; set-up times: medium; sequencing dependency: medium; part flow: one-piece/lot-wise; material flow complexity: medium; capacity flexibility: low; load flexibility: medium.

\section{Conclusion}

The studied case environment demonstrated an overall low applicability of the theoretical RCCP methods. It can be concluded that the fit of RCCP methods to the planning environment is relatively less influenced directly by the manufacturing process as compared to the market and product characteristics. The case study also revealed that existing mapping frameworks $[3,13,18,20]$ lack 'production monitoring accuracy' as an environmental variable. Production monitoring accuracy refers to the accuracy of data that is used to monitor actual production with respect to planned production. The availability and reliability of this data was found to play a vital role in the success of the delivery date setting process by providing information about available capacity in different planning periods, and was found to be a factor in the low delivery precision observed at the case company. More comprehensive investigation of the influence of production monitoring data on delivery date setting is a possibility for future work.

\section{References}

1. Berry, W.L., Hill, T.: Linking systems to strategy. International journal of operations \& production management 12(10), 3-15 (1992)

2. Blackstone, J.H. (ed.): APICS Dictionary Fourteenth edition. APICS (2013)

3. Buer, S.V., Strandhagen, J.W., Strandhagen, J.O., Alfnes, E.: Strategic fit of planning environments: Towards an integrated framework. In: International Conference on Information Systems, Logistics and Supply Chain. pp. 77-92. Springer (2016)

4. Burcher, P.G.: Effective capacity planning. Management Services 36(10), 22-5 (1992)

5. Carvalho, A.N., Oliveira, F., Scavarda, L.F.: Tactical capacity planning in a realworld eto industry case: An action research. International Journal of Production Economics 167, 187-203 (2015)

6. Carvalho, A.N., Oliveira, F., Scavarda, L.F.: Tactical capacity planning in a realworld eto industry case: A robust optimization approach. International Journal of Production Economics 180, 158-171 (2016)

7. Ebadian, M., Rabbani, M., Torabi, S., Jolai, F.: Hierarchical production planning and scheduling in make-to-order environments: reaching short and reliable delivery dates. International Journal of Production Research 47(20), 5761-5789 (2009)

8. Fogarty, D.W., Hoffmann, T.R.: Production and inventory management. Thomson South-Western (1983)

9. Gosling, J., Hewlett, B., Naim, M.M.: Extending customer order penetration concepts to engineering designs. International Journal of Operations \& Production Management 37(4), 402-422 (2017)

10. Hans, E.W., Herroelen, W., Leus, R., Wullink, G.: A hierarchical approach to multi-project planning under uncertainty. Omega 35(5), 563-577 (2007) 
11. Hicks, C., McGOVERN, T., Earl, C.F.: A typology of uk engineer-to-order companies. International Journal of Logistics 4(1), 43-56 (2001)

12. Hicks, C., Earl, C.F., McGovern, T.: An analysis of company structure and business processes in the capital goods industry in the uk. IEEE Transactions on engineering management 47(4), 414-423 (2000)

13. Jonsson, P., Mattsson, S.A.: The implications of fit between planning environments and manufacturing planning and control methods. International Journal of Operations \& Production Management 23(8), 872-900 (2003)

14. Kingsman, B., Worden, L., Hendry, L., Mercer, A., Wilson, E.: Integrating marketing and production planning in make-to-order companies. International Journal of Production Economics 30, 53-66 (1993)

15. Konijnendijk, P.A.: Coordinating marketing and manufacturing in eto companies. International Journal of Production Economics 37(1), 19-26 (1994)

16. Lödding, H.: Handbook of manufacturing control: Fundamentals, description, configuration. Springer Science \& Business Media (2012)

17. Olhager, J.: The role of the customer order decoupling point in production and supply chain management. Computers in Industry 61(9), 863-868 (2010)

18. Olhager, J., Rudberg, M.: Linking manufacturing strategy decisions on process choice with manufacturing planning and control systems. International Journal of production research 40(10), 2335-2351 (2002)

19. Rudberg, M., Olhager, J.: Manufacturing networks and supply chains: an operations strategy perspective. Omega 31(1), 29-39 (2003)

20. Schönsleben, P.: Integral logistics management: planning and control of comprehensive supply chains. CRC Press (2016)

21. Semini, M., Haartveit, D.E.G., Alfnes, E., Arica, E., Brett, P.O., Strandhagen, J.O.: Strategies for customized shipbuilding with different customer order decoupling points. Proceedings of the Institution of Mechanical Engineers, Part M: Journal of Engineering for the Maritime Environment 228(4), 362-372 (2014)

22. Sriram, P.K., Alfnes, E.: Taxonomy of engineer-to-order companies. In: IFIP International Conference on Advances in Production Management Systems. pp. 579587. Springer (2014)

23. Stevenson*, M., Hendry, L.C., Kingsman, B.G.: A review of production planning and control: the applicability of key concepts to the make-to-order industry. International journal of production research 43(5), 869-898 (2005)

24. Vollmann, T., Berry, W., Whybark, D.: Manufacturing Planning and Control Systems. Irwin/McGraw-Hill (1997)

25. Watanapa, B., Techanitisawad, A.: Simultaneous price and due date settings for multiple customer classes. European Journal of Operational Research 166(2), 351$368(2005)$

26. Wortmann, J.C., Muntslag, D.R., Timmermans, P.J.: Why customer driven manufacturing. In: Customer-driven Manufacturing, pp. 33-44. Springer (1997)

27. Yang, L.R.: Key practices, manufacturing capability and attainment of manufacturing goals: The perspective of project/engineer-to-order manufacturing. International Journal of Project Management 31(1), 109-125 (2013)

28. Zorzini, M., Corti, D., Pozzetti, A.: Due date (dd) quotation and capacity planning in make-to-order companies: Results from an empirical analysis. International Journal of Production Economics 112(2), 919-933 (2008)

29. Zorzini, M., Hendry, L., Stevenson, M., Pozzetti, A.: Customer enquiry management and product customization: An empirical multi-case study analysis in the italian capital goods sector. International Journal of Operations \& Production Management 28(12), 1186-1218 (2008) 